\title{
Skeleton keys
}

What was your first experiment as a child?

I have been fascinated by skeletons since the age of six. One of my early adventures was to unearth a medieval human skull from a ditch near an old church. As I was brought home by a policeman with the skull under my arm, obstinately refusing to put it back, my father agreed with the policeman that I could keep the skull for a while and then return it to its eternal rest. I cleaned the skull, restored it, and kept it for many years. Then I began to mount skeletons of animals I found dead on the roadside. This made the family kitchen look like an autopsy lab.

One day, I discovered an abandoned slaughtering-place in the forest. Here I unearthed century-old carcasses of horses, cows, goats, donkeys and so on (I was blessed with much room at home, and ignorance of anthrax). By mounting so many skeletons, I discovered that what attracted me was, essentially, homology. Nothing was more satisfying to me than discovering that, for example, the wishbone was the clavicle. Later, I turned to the fossil vertebrates of my native Touraine. Fragmentary bones of fish, crocodiles, rhinos and other fossil mammals revealed more amazing homologies. Much later, the same motivation led me to tackle the anatomy of weird and far older fish.

What book has been most influential in your scientific career?

Systematics and Biogeography, Cladistics and Vicariance by Gareth Nelson and Norman Platnick was like a cold shower and made me think in an entirely different way.

What gives you the most job satisfaction now? What are your frustrations?

The supreme delight is to find, by chance, something entirely unexpected.In this respect, field work in the Palaeozoic rocks of South America is a favourite source of satisfaction. My frustration lies in not being fully able to understand all the exciting papers in developmental genetics that come out these days.

What was the most memorable comment you ever received from a referee?

By some mischance a copy of one of my manuscripts contained the same page twice, yet one of these pages was placed far from its twin. For one paragraph of the first of these exactly similar pages, a referee wrote in the margin "yes, excellent", and for the same paragraph of the other page: "remove this".

Where and when would you most like to have lived or worked?

France, in the second half of the eighteenth century.
Before or after 1789 ?

Both. I should have liked to have been a middle-class provincial (perhaps a physician) in the time of the enlightenment, then experience the revolution and, notwithstanding the risk of experiencing the guillotine, die peacefully before the fall of 'the dwarf'.

What book currently resides on your bedside table?

The translation of Gregory of Tours' Historia Francorum, which I often re-read when I am worried by problems in scientific politics. It makes me realize that things could be worse.

What literary character would you employ as a postdoc?

Jules Verne's Captain Nemo.

Assuming the dead can be raised and/or time travel exists, who from the world outside science would you most like to have dinner with?

Aristotle (notwithstanding the probable frugality of the dinner).

You are on a plane behind two students obviously going to the same conference, who start to talk aboutyour work. What do you do?

Insert ear-plugs and say nothing.

What one thing would you rescue from your burning laboratory?

My copy of the Handbuch der Vergleichenden Anatomie der Wirbeltiere, edited by Bolk, Göppert, Kallius and Lubosch (1931-1937). It is an incomparable source of data, not otherwise readily available, and would be enough for mulling over vertebrate phylogeny for years on a barren island.

What would you have become, if not a scientist? A chef (note: I have changed since I boiled decaying hedgehogs in my parents' kitchen).

\section{What's your motto?}

Never answer "yes" immediately.

What previously under-recognized sport or pastime should be included in the Olympic Games?

Hagfish-catching (with hands only).

What single discovery, invention orinnovation would most improve your life?

A machine for expanding space (especially houses and flats) without limit.

What overlooked or underrated discovery really changed the science in which you work?

The use of acetic acid to etch fossils from limestone.

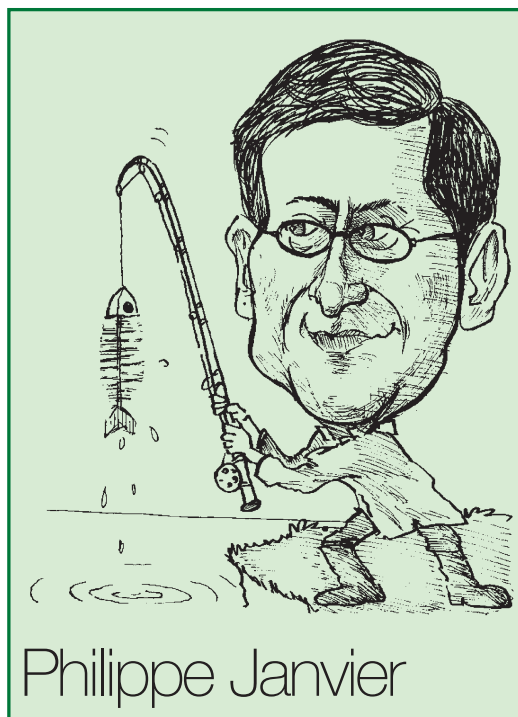

Philippe Janvier is a palaeontologist at the CNRS and works at the Muséum National d'Histoire Naturelle in Paris, France. He is also an honorary research fellow at the Natural History Museum in London. He likes angling, cooking and loves eighteenth-century books.

You've just been told (in confidence) that the world will end tomorrow. What would you do next?

I would have fried gudgeon with Muscadet, then three-dozen snails (the small species Helix aspersa, not the big, Burgundy one) with a Cravant 2000, and finally goat's cheese (preferably an old, hard Sainte-Maure) with a Bourgueil 1996. (The gudgeon and snails caught and prepared by myself — part of the pleasure.)

What's the most interesting thing in your fridge? A can of Swedish surströmming (fermented Baltic herring), which will soon be out of date.

Do you have a burning ambition to do something of no practical or immediate value?

Restore a huge (but really huge) castle. Apart from that, I'd like to go to a rave party (just once, to see what it was like). I like techno music in small doses - I think it is a real innovation that could lead to an entirely new music. The great step will occur with the composition of 12-tone techno (perhaps using Schönberg or Berg as a base).

What music would you have played at your funeral?

Messiaen's The Lord's Nativity. It is admittedly a bit long and might be more suitable for a cremation. But, as a palaeontologist, I simply cannot accept cremation (this would ruin the profession).

The host at a dinner party has placed you next to God. What would you talk about?

Finalism. 